\title{
Weapons in Legal Rituals: Between Myth and Reality
}

\begin{abstract}
This article seeks to explore the significance of weapons in legal rituals mentioned in sources, such as sagas and laws. Similarities in the phrasing of various types of sources give reason to believe that it is possible to determine certain uses of weapons in Viking Age legal rituals. Such rituals, which shared essential features with legal procedure, consisted of sequences of activities involving phrasing, objects, and gestures to mark a transition from one legal status to another, and they could also convey, and act as preservers of, legal meaning. Examples show that oaths were sworn on weapons, and that they conferred legal validity at the assembly (vápnatak). Old Norse mythology explained and legitimised key values in society, and through it everyday people found a template for how to use weapons in legal rituals. Rituals are however dynamic, and hence the ritual objects may change over time. In the Viking Age weapons were objects laden with meaning, and it was probably the introduction of Christianity that led to them being banned from further use in legal ritual.
\end{abstract}

\section{Introduction}

This article investigates the role of weapons in Viking Age legal rituals. It will explore which weapons were used for specific legal contexts, by whom, and why. By analysing written sources, I will shed new light on an under-researched theme in Viking Age studies: weapons as expressions of communities that were based on law, justice and honour, in contrast to previous studies that have mainly considered weapons as expressions of violence and a warrior society. Through a text-critical approach to written sources, primarily from Norway and Iceland, I will analyse accounts of weapons, and their role in legal rituals.

According to a basic explanation of ritual by Catherine Bell, historian of religion, it is 'the idea that some acts are intrinsically different from others' (1997: 91), which focuses on human action in a socially and culturally specific context. However, another leading scholar in the field of ritual studies, the anthropologist Roy Rappaport (1999), sees it less as something culturally specific, and more as a universal concept. In other ways, Rappaport's view of ritual is similar to Bell's. Rappaport focuses on human action becoming more and more

Contact: Anne Irene Riisøy, E-mail: anne.irene.risoy@usn.no

${ }^{1}$ Department of Culture, Religion and Social Studies, University of South-Eastern Norway 
ritualistic, describing this phenomenon as a continuum: from the highly spontaneous with a great choice of expression and action (everyday behaviour) to levels of 'increasing formality' (Rappaport 1999: 32-3).

Behaviour that adheres to form tends to be punctilious and repetitive, gestures and postures are stylised, often performed at particular times and places, as well as in specific contexts. An example is the courtroom where cases are presented in an orderly fashion (Rappaport 1999: 32-3). The procedure is rigid, although with some variant aspects, enabling the participants to present the particulars of their dispute. This system ensures that consistent and orderly accounts of unique events are presented to the court. Other examples of events that have legal implications - which are even more formalised - are inaugurations and marriages (Rappaport 1999: 32-3). My view is that it is possible to assign some general characteristics to rituals, and that the most obvious distinguishing trait is the high level of formality. Thus ritual shares some key characteristics with 'legal procedure', which was crucial in early law (Feldbrugge 2009: 18) and essentially deals with phrases, actions and objects applied in a correct and specified order to change legal status, or settle disputes.

In the early phase of ritual studies there was a considerable focus upon the relationship between ritual and myth, as well as their origins. Today scholars have by and large ceased to ask questions about origin, although it is rather common to argue for some sort of relationship between ritual and myth. The Old Norse mythological world was replete with gods and heroes involved in various legal activities (Riisøy 2016 a; Riisøy 2016 b; Riisøy 2020). Myths often provide models for ideal and correct behaviour through the actions of their protagonists (Miller 2005), and can help to explain and legitimise norms, moral, and social institutions (Schjødt 2008: 67). Thus, when legal rituals are performed and communicated to others, ideally they compel participants to respect societal norms. Hence, rituals can have the same effect as laws, which is - arguably - to stabilise the social fabric, and to discourage individuals from pursuing unbridled self-interest (Miller 2005).

In some Old Norse myths, weapons were important for legal rituals, and in such contexts they were 'ritual objects' capable of inspiring awe (Vedeler 2018), with their own status and meaning (Patera 2012). The myths also provided people with a common foundation for understanding the role of these objects in the rituals (Vedeler 2018).

Various topics that are relevant for the use of weapons in Viking legal rituals have been researched. One example is the composition of weapons in $10^{\text {th }}$-century Norwegian graves, which displays a closer correlation between the weapons legally stipulated for free men (broadaxe or sword, a spear and a shield) than the weapons from the earlier Viking Age graves (Hofseth 1982; Solberg 1985). The composition of such weapon assemblages for specific social strata may have varied over time, and perhaps not everyone within the free population was in possession of the entire range of stipulated weapons (Solberg 1985). Such considerations would have been relevant for who could apply what weapons in legal rituals.

Several pertinent examples of oath swearing on weapons, and the use of weapons to acclaim verdicts, convene assemblies, as well as other ritualistic uses of weapons that had legal consequences, will be discussed below.

Duels (ON hólmgangr [Eng: literally going to the islet]) and einvígi (single combat) were also used to settle legal disputes, often regarding property claims, or women (Byock 1993; Falk 2004). ${ }^{1}$ However, since their use in duels was direct and not symbolic, and due to spatial constraints, they will only be mentioned briefly below. The latter also applies to 
the ritual use of weapons in explicitly political contexts, although a ceremony such as sverdtaka, where a man touched the hilt of the king's sword to symbolically enter the king's service, also had legal implications, marking the transition from one legal status to another (see sverðtaka and sverðtakari, Fritzner 1973 III: 619; eleven references on sverðtakari in Sigurðardóttir, Kjeldsen, Jacobsen et al. [ONP]).

My aim is to present all other uses of weapons in legal rituals, including: which weapons, by whom, and why. Related to the why is the relationship between the real world and Old Norse mythology. Finally, I will attempt to trace changes over time, with a particular emphasis on the role of religion for the application of weapons in legal rituals.

\section{Materials and methods}

The point of departure for my enquiries is pieces of information embedded in foreign chronicles, as well as laws, poems and sagas predominantly hailing from Norway and Iceland, based on material collected for earlier studies (such as Riisøy 2016 a). Additionally, I have reviewed the Norwegian laws and made extensive use of the online database ONP (Dictionary of Old Norse Prose). Archaeologically it is hard to link the presence and assumed use of weapons to legal rituals, apart from through depictions of martial scenes that are often interpreted as such. They include portrayals of duels on helmets from male graves in Swedish Uppland, dating from the late $6^{\text {th }}$ and early $7^{\text {th }}$ centuries (Helmbrecht 2019: 134). The Langobardic so called Agilulf plate embellishes a helmet, which shows King Agilulf (r. AD 590-616) surrounded by warriors ostentatiously holding their spears, may be a representation of an acclamation at a gairethinx (Langobardic: spear assembly) (Dilcher 2006 b).

The methodological obstacles encountered in written sources are palpable, since Christian scribes did not pen the potentially Old Norse material to parchment until the $13^{\text {th }}$ and $14^{\text {th }}$ centuries. Consequently, a fundamental question is whether it can be used to explore and interpret Viking legal rituals?

A useful method for exploring the legal aspects of written sources relating to the Old Norse culture is Jens Peter Schjødt's so called 'genetic comparison' (Schjødt 2012). A prerequisite for using this method is that the compared cultures are historically related, and that they may have influenced each other through common heritage, or loans. In practice, this means that scant and inadequate sources can be complemented by sources from another area, which can aid the reconstruction of a larger system. Schjødt uses three different levels of comparisons: the Old Norse area; neighbouring cultures, such as the southern Germanic peoples; and the entire Indo-European area (Schjødt 2012). For my study of Norwegian and Icelandic medieval accounts of Old Norse customs, comparisons with the second level are most relevant.

Pertinent analogies appear in the earliest continental Germanic laws Leges Barbarorum, dating from the $5^{\text {th }}$ to the $9^{\text {th }}$ centuries, where shields, spears, swords and arrows were used in legal rituals (Hüpper-Dröge 1981: 120), suggesting that such practices were not invented by Norwegian and Icelandic scribes. It can be argued that remnants of an older and geographically wider Germanic legal past are echoed in the Viking world. Pending the Second World War philologists for example, still used the term Germanic, however, after the war it was shunned by legal historians, because of its misuse by the Nazis. In recent years, the 
pendulum has swung and notable legal historians have reintroduced the term to describe facets of the Leges Barbarorum, especially when addressing aspects that cannot be attributed to influences from Christianity and Canon law. This does not imply that there was ever a unified Germanic legal culture, as the sources reveal considerable geographical and chronological differences (Wormald 2003; Fruscione 2006; Oliver 2011).

Nordic medieval laws display glimpses of weapons as legal objects, particularly the oldest laws from Norway, where the earliest manuscript fragments are from around AD 1200. Rune Røsstad's philological study of selected legal texts, including the southwestern Norwegian Gulathing Law, indicates that the law contains material originating in the Viking age, and suggests that old legal rules may have retained their essence over time, despite several transcripts (Røsstad 1997). Moreover, in terms of content, the Gulathing Law and the northern Frostathing Law, display common Germanic features that pertain to resolving personal affronts, either by compensation, preferably in rings (ON baugr sing.), or through revenge (Skre 2017; Riisøy 2020). Below, I will therefore assume that the secular parts of these laws may contain material that is relevant for the legal practices of the Viking Age.

The Family sagas (Íslendingasögur), where the plots are set between the time of Iceland's settlement and the early $11^{\text {th }}$ century, which were not written down until the $13^{\text {th }}$ and $14^{\text {th }}$ centuries, may contain some fairly reliable information about past legal events. This supposition is supported by a comparison with the Sturlunga sagas (so called Contemporary sagas from AD 1117-1284). It has been suggested that the distinguishable differences between the descriptions of criminal law in these two saga genres supports arguments stating that the Family sagas reflect an older legal stage (Heusler 1911: 1-18), which can also be applied to more specific topics, such as goading and revenge (Mundal 1994), and to characterisations of the worst kinds of outlaws as (ON vargr) (Ersland 2001). This implies that oral traditions describing legal matters could persist for hundreds of years in conservative and stable farming communities, which is also supported by Bjarne Hodne's study of Norwegian post-Reformation stories about violence and manslaughter. When Hodne compared such stories collected in the $19^{\text {th }}$ and early $20^{\text {th }}$ centuries with original court records from the late $16^{\text {th }}$ and $17^{\text {th }}$ centuries, he found that the information coincided to a large degree (Hodne 1973). Linguistic analyses and the strength of oral traditions also suggest that Eddic poems - the best source for Old Norse myths - contain credible accounts of the use of weapons as legal objects and that many of their traits are pre-medieval, despite the fact that they were not written down until the High Middle Ages in Iceland, (Sävborg 2004; Porgeirsson 2016; Thorvaldsen 2016).

When considering that oral tradition was infinitely stronger in the Middle Ages than it is today (see also Brink 2002), it is not surprising that laws, sagas and poetry contain archaic terminology and legal accounts that are considerably older than the earliest surviving manuscripts. Hence, these sources are relevant for my article. I will begin by describing oaths used in rituals, followed by the use of weapons to acclaim verdicts or laws, convene things, or to establish geographical limits, measures, or boundaries. I will also discuss which weapons were used by whom and why, and how mythology and religion had a bearing on the use of weapons in legal rituals. 


\section{Results and discussion}

There are obvious similarities in the phrasing and structure of Old Norse sources, and chronicles written abroad that mention Viking weapon rituals outside Scandinavia. Since the chronicles written abroad and the Old Norse sources are not directly related, this would suggest that the similarities they contain may refer to verbal accounts of elaborately spoken formulas, as well as portrayals of ritual objects, and that they bear a semblance to how oaths were actually sworn. In this context the following statement regarding a treaty between the Rus' and the Byzantine Greeks, confirmed by oath swearing, is pertinent: 'it was commanded that the remarks of both parties should be inscribed upon parchment' (SherbowitzWetzor 1953: 73).

The fixed procedures mentioned in the table caption below find resonance in Old Norse sources, such as in the ornate trygða mál (English: peace guarantee speech: Grágás I, Dennis, Foote and Perkins 1980: 184-5), an account of a settlement confirmed by an oath. The final version, preserved in laws and sagas, is possibly from the mid- $10^{\text {th }}$ century. ${ }^{2}$ According to the trygða mál preserved in the early medieval Icelandic law-collection Grágás, anyone who breaks 'treaties' and 'sureties' shall be the worst kind of '[...] outcast [ON: vargr] despised and driven off as far and wide as ever [...]', followed a string of alliterative poetic word pairs, such as 'ship glides, shields flash, sun shine' (Dennis, Foote and Perkins 1980: 184-5). Examples from mythology also show that oath breakers were condemned as vargr (Sigrdrifumál, stanza 23; Neckel and Kuhn 1983: 194, see also Voluspá stanza 39, Neckel and Kuhn 1983: 9; Riisøy 2016 a).

Norse mythology is replete with gods and heroes well versed in oath swearing, and in addition to weapons, suitable oath objects were rings, the sun, holy stones and high-seat

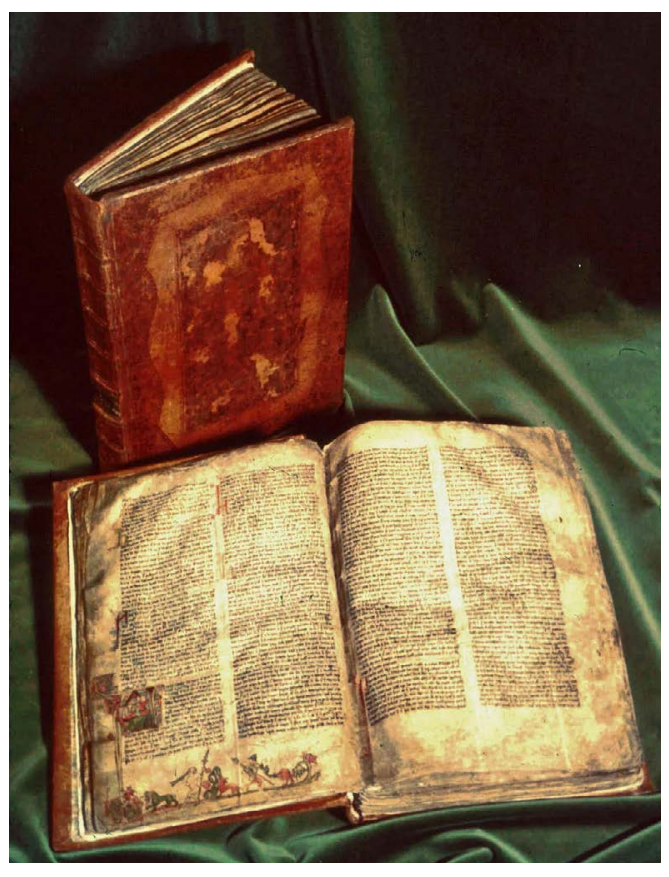

Figure 1. The Icelandic manuscript Codex Regius of the 1270s, in which many Eddic poems are preserved. $\mathrm{CCO}$ 


\begin{tabular}{|c|c|}
\hline Year, reference, and source & Weapons and relevant phrasing \\
\hline $\begin{array}{l}\text { 1) } A D \text { 811, a peace between } \\
\text { Charlemagne and Hemming, King of } \\
\text { the Danes (Scholz 1970: 93). }\end{array}$ & $\begin{array}{l}\text {... was only sworn on arms because of the severity of the winter' and with the return of spring, twelve } \\
\text { magnates of each party and people, that is of Franks and Danes, met on the River Eider at Heiligen and } \\
\text { confirm the peace by an exchange of oaths according to their customs.' }\end{array}$ \\
\hline $\begin{array}{l}\text { 2) AD 845, Danes, Carolingians } \\
\text { (Steenstrup } 2 \text { 1878: 155). }\end{array}$ & $\begin{array}{l}\text { During the siege of Paris, Viking leaders promised King Charles and 'swore by their gods and their } \\
\text { weapons' that they would not enter his kingdom as enemies. }\end{array}$ \\
\hline $\begin{array}{l}\text { 3) AD 873, Danes, Carolingians (Tschan } \\
\text { and Reuter 2002: 36, Reuter 1992: 71). }\end{array}$ & $\begin{array}{l}\text {... swore to 'a firm peace on their arms, according to the usage of the folk' (Adam of Bremen); 'swore on } \\
\text { their weapons, according to the custom of that people' (Annals of Fulda). }\end{array}$ \\
\hline $\begin{array}{l}\text { 4) Early 900s, Danes and Irish, Wirral } \\
\text { (Cavill, Harding and Jesch 2000: 22-3). }\end{array}$ & $\begin{array}{l}\text { '... will be swearing by their swords and by their shields, as is their custom, they will lay aside all their } \\
\text { missile weapons.' }\end{array}$ \\
\hline $\begin{array}{l}\text { 5) Rus', AD 907-11 (Sherbowitz-Wetzor } \\
\text { 1953: 65). }\end{array}$ & $\begin{array}{l}\text { 'Thus the Emperors Leo and Alexander made peace with Oleg, and after agreeing upon the tribute and } \\
\text { mutually binding themselves by oath, they kissed the cross, and invited Oleg and his men to swear an } \\
\text { oath likewise. According to the religion of the Russes, the latter swore by their weapons and by their } \\
\text { god Perun, as well as by Volos, the god of cattle, and thus confirmed the treaty'. Perun, the God of } \\
\text { thunder, was perhaps merged with the Old Norse god Thor. }\end{array}$ \\
\hline $\begin{array}{l}\text { 6) Rus', AD } 912 \text { (Sherbowitz-Wetzor } \\
\text { 1953: 66). }\end{array}$ & $\begin{array}{l}\text { In order to confirm an agreement on amity and peace, the Rus' used an 'oath sworn upon our weapons } \\
\text { according to our religion and our law'. }\end{array}$ \\
\hline $\begin{array}{l}\text { 7) AD } 945 \text { (Sherbowitz-Wetzor 1953: } \\
\text { 74). }\end{array}$ & $\begin{array}{l}\text { A curse over violators of the treaty: 'may they not be protected by their own shields, may they rather be } \\
\text { slain by their own swords, laid low by their own arrows or by any of their own weapons' In this case it is } \\
\text { not explicitly stated that an oath was sworn on weapons, however, the phrasing strongly indicates that } \\
\text { this was the case. The purpose was to establish friendship between the Rus' and the Emperors of } \\
\text { Greece (Byzantium). }\end{array}$ \\
\hline $\begin{array}{l}\text { 8) AD } 945 \text { (Sherbowitz-Wetzor 1953: } \\
\text { 77). }\end{array}$ & $\begin{array}{l}\text { The Rus' swore on a document that regulated various cases such as assault, manslaughter and theft, } \\
\text { involving Rus' and Greeks, and if the oath was broken 'may he perish by his own arms'. Before } \\
\text { unbaptised Rus' swore, they were expected to 'lay down their shields, their naked swords, their armlets, } \\
\text { and their other weapons', and, if the oath was violated 'he shall merit death by his own weapons'. }\end{array}$ \\
\hline $\begin{array}{l}\text { 9) AD } 971 \text { (Sherbowitz-Wetzor 1953: } \\
\text { 90). }\end{array}$ & $\begin{array}{l}\text { If the peace treaty confirmed by oath was broken, 'may we be accursed of the god in whom we believe, } \\
\text { namely, of Perun and Volos, the god of flocks, and we become yellow as gold, and be slain with our own } \\
\text { weapons'. }\end{array}$ \\
\hline $\begin{array}{l}\text { 10) Helgaqvida Hundingsbana onnor } \\
\text { stanzas 31-3, (Neckel and Kuhn 1983: } \\
\text { 157-8; Larrington 1996: 138). }\end{array}$ & $\begin{array}{l}\text { Water, stone, ship, horse, sword. Here, Sigrun refers to the objects, which Dag swore upon, and turned } \\
\text { the oath into a curse. }\end{array}$ \\
\hline $\begin{array}{l}\text { 11) Volundarkvida stanza 33, (Neckel } \\
\text { and Kuhn 1983: 122; Larrington 1996: } \\
\text { 107). }\end{array}$ & $\begin{array}{l}\text { King Nidud swore at scips bordi /oc at scialdar rond, at mars bægi / oc at mækis egg (Eng: by the side } \\
\text { of a ship and the rim of a shield, the back of a horse and the edge of a blade). Nidud had to swear that } \\
\text { he would do no harm to his daughter, who was pregnant by his enemy. }\end{array}$ \\
\hline
\end{tabular}

Table 1. The table contains two examples of Vikings swearing oaths on weapons in the Eddic poems $(10,11)$; while a majority of sources mention unspecified weapons $(1,2,3,5,6,9)$; two specify swords and shields $(4,11)$, and one source mentions arrows in addition to swords and other weapons (7). The swearing of oaths on weapons - most commonly swords-also occurs in the Leges (Grundtvig 1871; Hüpper-Dröge 1981: 126; Grünzweig 2009: 347-8). There are explicit references to Danes and Rus'setting their weapons aside in the initial parts of the procedure $(4,8)$, which probably meant that the weapons were retrieved for the oath to be sworn upon. ${ }^{15}$ Thus, the weapons were temporarily removed from the rituals (for more general information on this behaviour see Patera 2012), which implies that the use of the correct behaviour in strict sequence was part of the ritual swearing of oaths. 8) also states that the friendly relations between the Rus' and the Greeks (i.e. Byzantines) 'may never be interrupted, as long as the sun shines and the world endures henceforth and forevermore'(Sherbowitz-Wetzor 1953: 77). It is quite possible that this specific phrasing indicates that this was part of a fixed formula since it occurs elsewhere as well (Sherbowitz-Wetzor 1953: 74; Stein-Wilkeshuis 2002). 
posts (Riisøy 2016 a). Presumably, Vikings did not bring heavy objects - such as sacred white stones - on their journeys, whereas weapons were readily available. Practicalities aside, the most important aspect may have been that different kinds of oath objects pertained to different social contexts. ${ }^{3}$ Weapons can for instance symbolise strife, violence and war, and were therefore suitable objects for oaths sworn in connection to various peace agreements, as seen in table 1. It seems as if oath breakers were presumed to be subject to punishment from the objects upon which they swore, which is explicitly stated in some of the oath-confirmed treaties between the Rus' and the Greeks (Byzantines) that stipulate that Rus' breaking an oath should be slain by their own weapons (Table 1: 7, 8, 9).

The most obvious mythological parallel to such imprecations is found in the Eddic poem Helgaqviða Hundingsbana onnor (Table 1: 10): when Sigrún's brother Dagr had slain her husband, the hero Helgi, Sigrún wished that all the oaths Dagr had sworn on to Helgi would rebound on him, and that the objects upon which Dagr swore, the ship and the horse, would fail him. Helgi had also sworn upon his sword, which Sigrún uses to end her curse: 'May the sword that you wield never bite for you / unless it's whistling above your own head' (ON: Bitia pér pat sverð, er pú bregðir, / nema siálfom pér syngvi um hofði). Here the words of the oath were turned into a poetic curse implying that the oath object would turn against the oath breaker (Thorvaldsen 2010, cf. Grundtvig 1871).

\section{Weapons used to acclaim, summon, and to establish limits and measures}

The earliest Norwegian laws specifically prescribe vápnatak as the legal confirmation of buying, selling and redeeming óðal land (G 267, G 279, G 292, F XII 2, F XII 4, F XIV 4; NgL I: 89, 93, 96, 236-7, 249-50). The term vápnatak was useful, and took on different meanings in different areas colonised by Scandinavians. In Iceland vápnatak came to mean the end of the proceedings at the alpingi, and in the $12^{\text {th }}$ and $13^{\text {th }}$ centuries eptir (after) vápnatak had become a set term for a deadline (Finsen, Ordregister in Grágás 1883: 687-9, [A selection of terms] for the former Grágás I, 1980: 275 'close of assembly'). The term vápnatak entered Old English as waepengetetcec (wapentake) and became the name for a legal administrative district, or thing area, in the Danelaw (Hüpper-Dröge 1981: 121; Baker and Brookes 2013).

Remnants of practices where weapons were used in land-transfer procedures are also visible in medieval Swedish law. Stefan Brink (2011: 154) notes that, according to the Östgöta Law, fasta (OSwe: holding the shaft of a spear) was conducted when land was sold, divided, given away, or pledged. Such uses of weapons may have far older precedents, and it has been suggested that the primary function of the gairethinx (literally spear assembly) in Langobardic law dealt with property transfer but also with matters relating to the manumission of slaves, and the acclamation of verdicts or laws (Dilcher 2006: 434). ${ }^{4}$

The use of weapons to acclaim verdicts also existed in Danish law. Chapter 90 in The Liber legis Scaniae, concerning theft, stipulates that if the defendant does not appear - after repeatedly being summoned to the district assembly - the defendant shall be considered as 'the kind of person called frithløs in the native language; and this will be clearly expressed both by words and by "the visible striking together and touching of arms" (collisione armorum et contact), so that anyone is permitted to assault him with arms' (Tamm 2018: 102-3. This law was probably written down in the first part of Anders Sunesen's period as archbishop, which began in 1201, Tamm 2018: 5). 
Although the terminology differed between various Germanic peoples, the use of weapons to acclaim a verdict may have been a common Germanic practice (Green 2002: 119). ${ }^{5}$ Already in the $1^{\text {st }}$ century the Roman historian and politician Tacitus observed that if a proposal pleased a Germanic assembly, 'they elevate their frameae [spears]: the most honourable sort of approbation is to applaud with arms' (si placuit (sententia) frameas concutiunt, honoratissimum assensus genus est armis laudare) (Germania 11. 1, Rives 2002: 81-2, 172), suggesting a legal ritual similar to the Old Norse vápnatak (e.g. Hertzberg 1874: 148-52).

An arrow, inscribed with the name of the accused, was used to summon an örvarping (arrow thing) after a killing, or in other cases of serious bodily harm. Such a ping was held ad hoc, and the accused, as well as witnesses should be present (G 156, G 160, F IV 29, F IV 54, F V 7, F V 12, NgL I: 61-3, 167, 173-4, 177, 179). It was imperative to use the correct object to summon such an assembly, and a plaintiff could lose a case 'if an arrow [was] sent forth when a thing token (only) [was] required'; an incorrect summons also meant that a suspect could not be convicted (F V 12, NgL I: 179, Larson 1935: 286). The use of an axe was also required in some legal situations. According to a wergild-system paragraph in the Gulathing Law (concerning compensation for murder or other violent crimes), 'when the slayer dies his heir assumes the responsibility for the axe', meaning that the heir took over the responsibility to pay the wergild (G 218, NgL I: 74, Larson 1935: 150; Robberstad 1969: 380). ${ }^{6}$ Another example was when a man who had had his tongue cut out recognised the perpetrator at the assembly, he should poke the perpetrator with his axe handle, thus making the offender an outlaw. In cases when perpetrators did not attend the assemblies, the maimed should write the name of the accused in runes, alternatively explain to the assembly what the truth was by using gestures (F IV 43, NgL I: 171: Larson 1935: 275).

Weapons were also used to determine the size - or extent - of legal measures. ${ }^{7}$ In accordance with Rappaport's continuum (Rappaport 1999), I consider some of these practices to be more ritualistic than representations of spontaneous everyday behaviour. One example is the so called beingiölld (bone compensation), when a shield was used to determine the size of compensation due to a victim based on the size of the piece of bone lost. This entailed listening to the sound of the bone 'rattling on the shield' (skellr á skialldi) (F IV 49, NgL I: 172), alternatively bones 'rattling in a bowl' (skellr i skalom) (G 185, NgL I: 67). Strikingly similar rules appear in various Leges (Hüpper-Dröge 1981: 120-1). Another example involved determining the size of an örskotshelgi (arrow sanctuary), an Icelandic custom where the length of an arrowshot established the legal and sacred limits of three different sanctuaries for a fjörbaugsmaðr (lesser outlaw). A fjörbaugsmaðr was also guaranteed safe passage on the roads connecting the three sanctuaries, as long as he kept more than a spear length off the road when encountering other travellers (Grágás I, 1980: 263; NgL 5: 760, örskot-helg). A third example is a custom called tundror: when a burning arrow was shot to mark a land claim during the Icelandic settlement period (KLNM 3: 580, 13: 313-4). There is further evidence for the use of weapons to determine legal measures scattered here and there in the earliest Norwegian laws, however, in those instances to establish specific units - rather than as a ritual.

With regard to the use of weapons to acclaim verdicts, summon assemblies, and determine legal measures, no mythological parallels have survived. It is of course possible that they never existed, since these were rather unspectacular, mundane, affairs. 
Which weapons were used, by whom, and why

In legal procedures oaths could be sworn upon any of the legally stipulated weapons (described above, and later in this section). Moreover, weapons such as swords and shields, as well as halberds and spears, were used in duels, which had legal implications, and was seen as part of legitimate procedure. As suggested above, the social context may have determined the type of oath object chosen, and oaths sworn on weapons may have been particularly suitable for peace arrangements of various kinds. Among the weapons that acclaimed verdicts spears seem to have been the most common, probably since they were the most visible when raised into the air. They were also less costly than swords, and readily available to all free men. The presence of such customs is supported by other Germanic contexts, such as the Langobardic gairethinx, and Tacitus descriptions. Finally, various weapons were used to determine legally valid measures, and as I have shown above, some of these practices would have been ritualistic.

Legal status, as well as gender, may have had a bearing on whether a person was allowed to use weapons, and of what kind, in legal rituals. Not all free men were in possession of a whole range of weapons (Solberg 1985). Since swords were the most expensive weapons, they also signified the highest social status. Hence, some people swore the oaths on swords, while others presumably had to make do with arrows. ${ }^{8}$

Slaves had no association to weapons, or legal rituals, and generally they lacked legal protection, réttr and mannhelgi. According to Grágás they had to be led into the log (law) by a goði (someone who was a chieftain and a cultic leader) to receive full free status (Iversen 1997: 65, 228). Presumably the use of weapons was reserved for the free, since all frialser (free) had a legal duty to attend and display their weapons for inspection at the vápnaping (G 309, F X 3, NgL 1: 101, 217-8; vápnaping, NgL 5: 688). The weapons stipulated for a full set of arms in the early medieval Norwegian laws were broadaxes or swords, spears and shields (Solberg 1985; Aannestad 2018). Arrows and bows are not mentioned, presumably because they were the least costly, and hence perhaps taken for granted.

I have not come across any other examples of weapons signifying legal status in Norse texts, however, some intriguing traces of such a practices have survived from other Germanic sources. Arrows were part of manumission rituals in Langobardic law. The rather elaborate ceremony involved a confirmation by the gairethinx, and at the end the slave - whether 'man or woman' - was presented with an 'arrow and a whip', the symbols of freedom (Rothair's Edict, § 224 On manumission, Drew 1973: 96, 248, note 61; Hüpper-Dröge 1981: 123-4). This manumission description is supported by Paulus Diaconus in Historia Longobardorum, 'they confirm it in their accustomed way by an arrow' (Historia I, 13, Peters 2003: 21, Dilcher 2006: 430-1). Other examples of weapons used in matters relating to legal status include shields, which may have been symbols of free men capable of defending themselves, or perhaps representing some sort of 'judicial peace' (German: Gerichtsfriedens). Shields also had to be presented at the assembly by anyone wishing to marry a widow, or adopt an heir (Hüpper-Dröge 1981: 120-2; Pactus legis Salicae 44, 1 and 46. I, Rives 1986: 90, 92, 156). ${ }^{9}$

It is important to note that heads of families of both sexes could represent their households at the ping (Sanmark 2014), and that it was allowed to carry weapons at the ping in Norway until it was banned in $1189 .{ }^{10}$ Free women probably also participated in legal rituals requiring weapons, such as the summoning of an örvarping with an arrow (see above). 


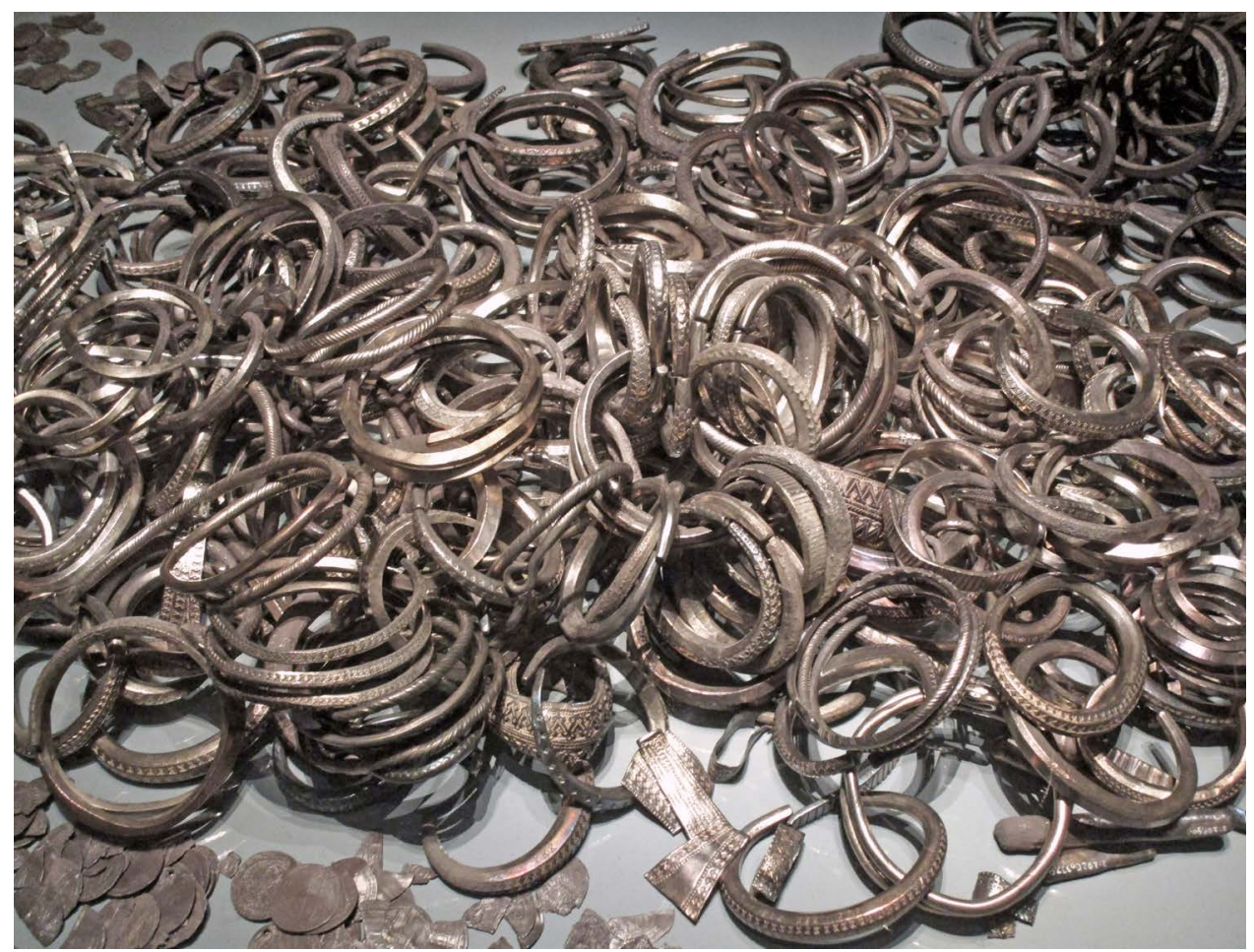

Figure 2. Parts of the Spillings Hoard, an exceptionally large silver hoard, found on Gotland in 1999 consisting of coins, bars, hacksilver and rings. CCO

Else Mundal has found further proof of the strong judicial status of Norwegian women in laws (1994, see also Riisøy 2016 b). In various situations women would swear oaths on whichever weapons they were in possession of, and they would also be able to acclaim verdicts by elevating spears, or even swords. According to early Icelandic and Norwegian law, a baugrygr (a ring lady, who was an only child and unmarried) was entitled to both pay and receive compensation in the form of wergild rings (Grágás I, 1980: 181; cf. G 275, F VI 4, NgL I: 92, 184-5), and hence, if her father died after having killed another person, she would have to live up to 'the responsibility for the axe' (see above). Moreover, according to the laws women themselves were allowed to kill, presumably while wielding weapons (Riisøy 2020). One example, from an archaic paragraph in the Gulathing Law, stipulates that a person, irrespective of gender was expected to avenge a wrong (G 186, $\mathrm{NgL} \mathrm{I}$ : 68).

The rights described in the previous paragraph may have implications for the interpretation of female burials containing weapons (see Gardeła 2013 and this volume; Moen 2019). The exploration of the role of women as potential warriors, could be complemented by studies of whether they had used the weapons they were buried with in legal rituals. Miniatures - such as miniature weapons - that are often found in female graves, ought perhaps also be analysed in the same context. Such questions, however, will require separate studies. 


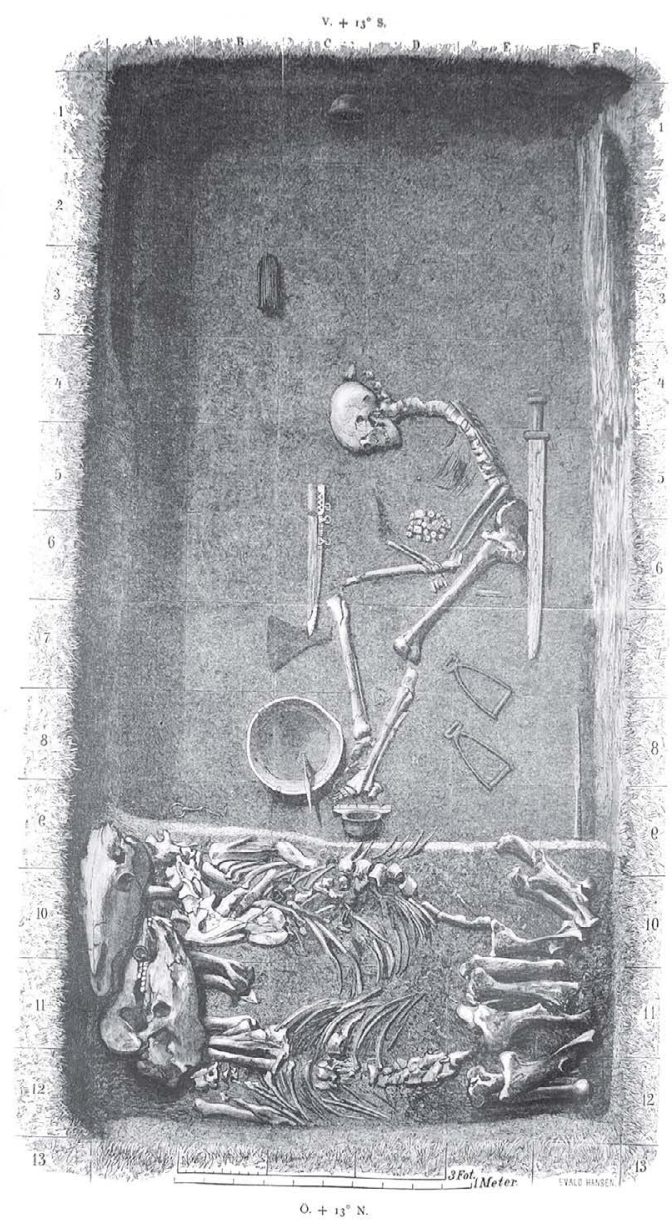

Figure 3. The most famous burial at Birka, Bj.581, which in recent years has attracted world-wide interest. Illustration: Hjalmar Stolpe, 1889. CCO
From a certain point in time - probably connected to the introduction of Christianity - a more negative attitude towards women with weapons is discernible. A unique paragraph preserved in Grágás stipulates lesser outlawry for women who fer með vápn (carry weapons) (ch. 254, Grágás, Finsen 1852: 203-4; Grágás II, Dennis, Foote and Perkins 1997: 219), which indicates that some women did carry weapons. In older Germanic contexts, weapon-wielding women were regarded more favourably, and Tacitus even describes a custom whereby a future husband would present his betrothed with a horse and shield, spear and sword (Germania 18, Rives 1999: 84). This probably reflects a genuine practice, as a similar rule of ancient origin appears in the early $7^{\text {th }}$-century Law of the Visigoths, which states that a fiancé should give his fiancée weapons as a morgingeba (Eng: nuptial gift, literally morning gift) (Kienast 1984: 254-6). This is an excellent example of weapon use in legal rituals, as marriage marked a change in legal status. However, I have not found any trace of similar rituals in Scandinavian sources.

\section{Between myth and reality, objects and words, paganism and Christianity}

Accounts of oaths and duels also appear in the Eddic poems. Regarding terminology, phrasing and principles, various sources display that there were great similarities between the world of myth and the real world, although less spectacular legal rituals may not have had any mythological connotations at all. When used in rituals, weapons would have taken on extraordinary properties, where the myths may have served as templates for their ritual function, and explained how they conferred authority, as well as tradition, upon such procedures. The breaking of legal agreements would have disturbed the societal balance, which was considered as dishonourable, and the perpetrators were hence condemned in the strongest terms, as níðingr (socially stigmatised cowards), and vargr, (the worst kind of outlaws).

In addition to objects, terminology was very important, as it brought structure and order to the legal process, and when combined, objects and words conveyed more authority than either would on their own. 
The sources provide glimpses of rather detailed and eloquent phrasing relating to oaths and duels, as well as to legal formalities in general. Legal eloquence and its importance is exemplified in an episode of Heiðarvíga saga. Here Torgisl is told that he is unsurpassed in terms of 'pronounc[ing] a pledge for peace or other legal formalities' (ch. 33, Hreinsson 1997, 4: 121-2). This relates to procedures where words, expressed through poetry, combined with appropriate objects - presumably as part of set formulas - may have facilitated public acceptance of various settlements and judgements. It also seems as if the same weapons could be used for different legal rituals, and similarly that the same formulaic phrasing could be appropriate for various legal contexts. ${ }^{11}$ There is evidence suggesting that the specific terminology used - often strung together in alliterations - reflects a far older Germanic legal culture. One example is the previously mentioned use of arrows in manumission rituals, which also contained 'Lombardic word formulas' (Historia I, 13, Peters 2003: 21, Dilcher 2006: 430-1). Sadly, the details of the formulas in question have not been preserved.

The links between law, religion and appropriate objects were strong, which is confirmed by expressions such as the ones used in an early $10^{\text {th }}$-century Rus' treaty: 'under a firm oath sworn upon our weapons according to our religion and our law' (Sherbowitz-Wetzor 1953: 66). Religion, as Marianne Vedeler (2018) puts it, is a 'game-changer', implying that the same objects may not have retained their ability to evoke awe after societal and religious change. Although somewhat simplified, accepting Christianity involved accepting some new ritual concepts (i.e. acts and objects), as well as rejecting others. The term siðr (a distant synonym to ritual) is appropriate in this context, as it refers to practice regarding custom, habit, tradition and religion, although it is clearly more associated to acts than to faith. Hence Christianisation was often described as a change of siðr (Clunies Ross 2002: 22, see also [ONP] Sigurðardóttir, Kjeldsen, Jacobsen et al.).

Although rituals appear ageless, they are dynamic, and ritual objects may change (Patera 2012). For new rituals to succeed they need to retain elements of older ones (Rappaport 1999: 32). In pre-Christian times the swearing of oaths, for example, were important procedures, and similar practices continued during and after the acceptance of Christianity. However, objects previously used - such as weapons - were discarded, while new objects were sanctioned by the Church, such as the Bible and the Cross (i.e. G 37, F IV 8, NgL I: 22-3, 160-1; Grágás, Finsen 1852: 46, 72). ${ }^{12}$ Since weapons and their legal ritual use also symbolised war and strife, as well as connections to pagan sacrifices and gods, some of the previous legal rituals were abandoned due to Christian dogma. ${ }^{13}$

Similar to the change of objects, terminology also changed with a new religious context. This is evident in the abovementioned trygða mál, which mixes Christian and pagan elements ('Christians come to church, heathens hallow temples'), suggesting that the preserved version derives from the religious transition period (Grágás I, Dennis, Foote and Perkins 1980: 184-5).

Other legal uses of weapons were also phased out or changed. ${ }^{14}$ One example was the use of weapons for determining legal measures and areas, which is clearly evidenced through a comparison between the older Norwegian provincial laws and King Magnus the law mender's landslov (1274). Another example, from Iceland, is the sanctuaries (örskotshelgi) of an outlaw, which were no longer arbitrarily decided by the length of an arrow shoot, but became fixed during the High Middle Ages (Ordregister in Grágás 1883: 712). At least indirectly, 


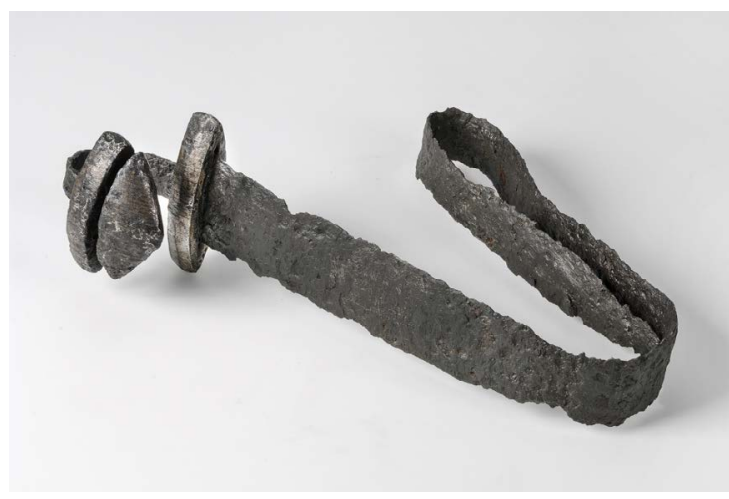

Figure 4. A bent sword from a grave in Backa, Västerfärnebo,

Västmanland, Sweden. Photo: from the exhibition We call them Vikings at the Swedish History Museum, SHM 20221. CC BY-SA 4.0

these changes were a result of Christianisation, as the arrival of writing on parchment gradually - but presumably also very slowly - replaced oral tradition as a means of preserving the laws.

Within the topic of weapons in legal rituals, another obvious avenue for future research is the question of whether some weapons in certain contexts were considered as agents. In other words, whether they were considered to cause events, and therefore to be potentially dangerous (Aannestad 2018, see also Grundtvig 1871 regarding oaths). For now, I will draw attention to a few interesting examples, which illustrate this point. Some of the oaths quoted above suggest a belief in weapons as animate objects that could harm an oath breaker (Table $1: 7,8,9,10)$. Weapons - mostly swords - were given names, and similarly to important people notable swords could accumulate impressive pedigrees and their own biographies through accompanying stories (Hedeager 2011: 138). The sword Dragvandill is an example. It was extremely sharp and had been used by the legendary hero Ketill hoengr in duels. Later, this sword ended up with Egill Skallagrímsson, who also used it in duels (Egils saga, ch. 62, Hreinsson 1: 126). Another intriguing saga episode explains how a sword initially intended for a duel was grasped by the blade and deliberately bent, after which 'it had lost all its temper' (Svarfdcela saga, ch. 8, Hreinsson 4: 159). Here, it may be possible to infer a connection between written sources and archaeology, due to a relatively high number of 'deliberately killed' (i.e. bent) swords found in Norwegian Viking Age graves, as well as in wetland deposits in Southern Scandinavia. It has been suggested that this may reflect a custom of removing potentially dangerous weapons (Aannestad 2018).

\section{Conclusion}

My aim with this article has been to understand the role of weapons in Viking Age legal rituals. When considering all my sources, I find it quite likely that they constitute a reliable account of the role of weapons in legal rituals, since they contain such obvious similarities regarding phrasing and structure, both within the Old Norse corpus, and through pertinent parallels to the older and geographically wider Germanic context.

Thus, it seems as when medieval scribes put laws, sagas, and poetry to parchment, they could apparently still relate to collective memories of how weapons were used in various legal rituals in pre-Christian times. 
Many scholars argue that during the Viking age war was endemic, and that weapons were 'means of power, and had symbolic importance as expressions of the warrior role and the warrior values' (Aannestad 2018: 163). Moreover, there was no apparent separation between the world of weapons and the legal sphere, as weapons reflected a number of important concepts for their communities, based on law, justice and honour. Words like sverðping (the meeting - or assembly - of swords) and vápndómr (judgement by arms) - as a kenning for battle - are poetic expressions that reflect actual ancient practices (Dumézil 1973: 43-4), although this does not necessarily mean that armed conflict and legal dispute should always be seen in the same light (Foote 1984).

Poetry is an important gateway into Viking Age mythology, which in turn explained and legitimised key values in society. The mythology helped set ethical standards for the aggressive behaviour, which signified Viking Age society (Sørensen 1983: 21; Riisøy 2020). This probably also explains why weapons were so frequent in legal rituals. In these rituals combinations of objects, expressions, and gestures may have been tailored to fit various parameters, such as legal contexts, social status, knowledge and learning, and religion.

\section{Notes}

1 Duels were connected to gods, mythological heroes, and men, and there are accounts of duels in a wide range of sources: Eddic and Skaldic poetry, sagas, and even in laws (G 216, NgL I: 74; NgL 5: 293, holmfcer; the hepnalagh 'pagan law' (Holmbäck and Wessén 1946: XXIII-XXVII).

2 A fragment of a trygða mál has been preserved in the Gulathing Law (G 320, NgL 1: 110), and recently it is thoroughly discussed by Jørn Øyrehagen Sunde (2007). A more complete version is found in the Icelandic lawbook Grágás. Possibly, the final version originated during the reign of King Håkon den gode (r. c. 935-61) which the inclusion of both pagan and Christian elements in the formula suggests, (see Riisøy 2016 a).

3 An oath sworn in connection to a marriage arrangement in Atlakviða includes the expression holkvi hvilbeðjar 'the bed's horse' (hollkvi, refers to horse and hvílbeðiar, beð to 'bed' or 'bedding'), which presumably denotes the carved horse's head on the end-posts of Viking Age beds (stanza 30, Neckel and Kuhn 1983: 245; Larrington 1996: 214, as argued for in Holtsmark 1941). In the context of marriage, a bed is an obvious object to invoke, and among its various important roles, the horse may also have been a symbol of fertility (Holtsmark 1941), The more famous ring oath may have been graded above other kinds of oaths, and in the Old Norse sources they are especially connected to the hof, laying on the 'altar' (stalli, stallr), and worn by the goði (plural goðar) i.e. someone who was a chieftain and a cultic leader (Riisøy 2016 a).

4 Transfer of property: $\S \S 167,172,173,174,375$; Drew 1973: 81-3, 126; emancipation, $\S \S 222,224$; Drew 1973: 95-6; approval of law; Epilogue, Edictus Rothari, proclaimed AD 643 and based on old tribal customary law, § 386; Drew 1973:129. Otherwise the gairethinx in the Langobard laws has come to mean a public act, which legally validated something, Drew 1973: 259; Hüpper-Dröge 1981: 122; Dilcher 2006 a: 422; Green 2009: 176-8).

5 Green 2009 finds that the earliest root of the English word 'to play' Old English plegan means 'to make violent movement' and 'to play with your spear, to play with your sword' and 'battle play', whereas in Old Saxon and Old High German plegan or pflegan means 'to accept responsibility for a legal decision'. In Norwegian medieval law vápnatak acclaimed a verdict at the assembly, outside the logrétta (literally 'law corrector', and the court of justice) which was demarcated by vébond 'sacred cords' (F V 46, NgL 1: 183; Magnus lagabøtes landslov, I: 5, NgL 2: 17; NgL 5: 356-8, 688, 741, vápnatak, see also pingtak and vápnabrak).

6 The Gulathing Law has several wergild systems; Robberstad 1969: 370-5 operates with five different wergild systems (saketal), and he considers G 180 to be the oldest of these. Another clear sign that this rule is pre-medieval is the compensation in rings (sing. baugr). I would like to thank Jørn Øyrehagen Sunde and Frode Iversen who suggested that I took a closer look at the axe. 
7 An arrow was used to establish the finder's share in whale blubber (G 150, NgL 1: 59-60). Those who were charged with petty theft, had to run the gauntlet, and were pelted with rocks and turf, and the course should be nine bows long (G 253, NgL 1: 82-3).

8 During the Merovingian period swords were not always explicitly mentioned as oath objects but instead unspecified 'weapons' were mentioned, perhaps because not all free had a sword, since the axe was more common and hence applied (Grünzweig 2009: 347-8).

9 The shield as a symbol of 'judicial peace' (Hüpper-Dröge 1981: 120-2) may have been more widespread and also have had a broader meaning. An episode in Fagrskinna set in the late Viking Age, for example, describes a white shield raised as a token of peaceful intentions (Finlay 2004: 119).

10 Personal communication with Frode Iversen.

11 A formulaic insult hurled at an absentee duellist in Vatnsdcela saga was also used to condemn an oath-breaker in trygða mál (Sørensen 1983: 30-1).

12 Similar changes took place among other Germanic peoples centuries earlier. In the mid- $6^{\text {th }}$ century the Franks were no longer allowed to swear by their right hands or their weapons, because it was a pagan custom, which should no longer apply to the Christian Franks (Grundtvig 1871).

13 Episodes of avenging pagan gods in Kristni saga are supported by Skaldic stanzas, which are likely to be genuine (Mundal 2012: 83).

14 Although duels are not in focus in this study it should be mentioned that they seem to have disappeared in the $11^{\text {th }}$ and $12^{\text {th }}$ centuries. Only traces of duels are found in laws, and the term hepnalagh (Holmbäck and Wessén 1946: XXIII-XXVII) implies that duels were considered to be a pagan custom, or that accompanying sacrifices and their pagan religious connotations certainly were. Olav Bø's presentation of Einvigi, KLNM III: 534, states that in the late $12^{\text {th }}$ century, Pope Alexander III wrote to the archbishop of Uppsala, prohibiting ordeals by hot iron, boiling water, and duels. The social context, that anyone had the right to challenge to a duel, may have been an additional reason why this procedure was abolished, at least in Norway and Iceland. According to the sagas, the prohibition of duels coincided in time with the acceptance of Christianity (Grettis saga, ch. 19, Hreinsson 1997, 2: 76; Gunnlaugs saga Ormstungu ch. 11, Hreinsson 1997, 1: 327).

15 The oath object is different, however, the gesture is similar when a rule in the Gulathing Law prescribes that an oath shall be taken before the Church door, and a book (boc) shall be laid on the threshold and consequently picked up by the person swearing the oath (G 30, NgL I: 18).

\section{Bibliography}

Aannestad, Hanne Lovise

2018 Charisma, Violence and Weapons. The Broken Swords of the Vikings. In Charismatic Objects. From Roman Times to the Middle Ages, edited by Marianne Vedeler, Ingunn Marit Røstad, Siv Kristoffersen and Ann Zanette Tsigaridas Glørstad, pp. 147-68, Cappelen Damm Akademisk, Oslo.

Andersson, Ingvar and John Granlund (editors)

1956-78 KLNM: Kulturhistorisk Leksikon for Nordisk Middelalder. 22 vols. Gyldendal, Oslo.

Baker, John and Stuart Brookes

2013 Governance at the Anglo-Scandinavian Interface: Hundredal Organization in the Southern Danelaw. Journal of the North Atlantic 5: 76-95.

Bell, Catherine

1997 Ritual: Perspectives and Dimensions. Oxford University Press, New York and Oxford.

Brink, Stefan

2011 Oral Fragments in the Earliest Old Swedish Laws? In Medieval Legal Process: Physical, Spoken and Written Performance in the Middle Ages, edited by Marco Mostert and Paul Barnwell, pp. 147-56. Brepols, Turnhout.

2002 Law and Legal Customs in Viking Age Scandinavia. In The Scandinavians from the Vendel Period to the Tenth century: An Ethnographic Perspective. Studies in Historical Archaeoethnology 5, edited by Judith Jesch, pp. 87-110. The Boydell Press, Woodbridge. 
Cavill, Paul, Stephen Harding and Judith Jesch (editors)

2000 Wirral and its Viking Heritage. English Place-Name Society, Nottingham.

Clunies Ross, Margaret

2002 Närvaron och frånvaron av ritual I norröna medeltida texter. In Plats och praxis. Studier av nordisk förkristen ritual, edited by Kristina Jennbert, Anders Andrén and Catharina Raudvere, pp. 13-30. Nordic Academic Press, Lund.

Dennis, Andrew, Peter Foote and Richard Perkins (editors and translators)

1980 Laws of Early Iceland: Grágás I. University of Manitoba Press, Winnipeg.

1997 Laws of Early Iceland: Grágás II. University of Manitoba Press, Winnipeg.

Drew, Katherine Fischer (editor and translator)

2003 The Lombard Laws. University of Pennsylvania Press, Philadelphia.

Dilcher, Gerhard

2006 a 'per gairethinx secundum ritus gentis nostrae confirmantes' - Zu Recht und Ritual im Langobardenrecht. In Leges-Gentes-Regna. Zur Rolle von germanischen Rechtsgewohnheiten und lateinischer Schrifttradition bei der Ausbildung der frühmittelalterlichen Rechtskultur, edited by Gerhard Dilcher and Eva-Marie Distler, pp. 525-35. Erich Schmidt Verlag, Berlin.

Dilcher, Gerhard

2006 b Exkurs: Die Agilulf-Platte als Zeugnis des langobardischen Gairethinx. In Leges-Gentes-Regna. Zur Rolle von germanischen Rechtsgewohnheiten und lateinischer Schrifttradition bei der Ausbildung der frühmittelalterlichen Rechtskultur, edited by Gerhard Dilcher and Eva-Marie Distler, pp. 449-58. Erich Schmidt Verlag, Berlin.

Dumézil, Georges

1983 Gods of the Ancient Northmen. University of California Press, Berkeley, Los Angeles, London.

Ersland, Gunnhild Vatne

2001 '... til død og fredløshed ...’’ fredløysas innhald og funksjon på Island frå 1117 til 1264.

Hovedfagsoppgave. Universitetet i Oslo.

Falk, Oren

2004 Bystanders and Hearsayers First: Reassessing the Role of the Audience in Dueling. In A Great Effusion of Blood? Interpreting Medieval Violence, edited by Mark D. Meyerson, Daniel Thiery and Oren Falk, pp. 98-130. University of Toronto Press, Toronto.

Feldbrugge, F. J. M

2009 Law in Medieval Russia. Brill, Leiden.

Finlay, Alison (editor and translator)

2004 Fagrskinna, a Catalogue of the Kings of Norway. A Translation with Introduction and Notes. Brill, Leiden, Boston.

Finsen, Vilhjálmur (editor)

1883 Grágás. Stykker, som findes i det Arnamagnaeanske Haanskrift Nr. 351 fol., Skálholtsbók og en Rcekke andre Haandskrifter. K. Gislason et al., Kjøbenhavn.

1852 Grágás. Isloendernes lovbog i fristatens tid. Brødrene Berlings bogtrykkeri, Kjøbenhavn.

Foote, Peter

1984 Things in early Norse verse. In Festskrift til Ludvig Holm-Olsen på hans 70-årsdag den 9. juni 1984, edited by Bjarne Fidjestøl, pp. 74-83. Ahrheim \& Eide, Øvre Ervik.

Fritzner, Johan

1973 Ordbog over Det gamle norske Sprog. 4 vol. Universitetsforlaget, Oslo, Bergen and Tromsø.

Fruscione, Daniela

2006 Eine philologische Schlußbemerkung. In Leges-Gentes-Regna. Zur Rolle von germanischen Rechtsgewohnheiten und lateinischer Schrifttradition bei der Ausbildung der frühmittelalterlichen Rechtskultur, edited by Gerhard Dilcher and Eva-Marie Distler, pp. 525-35. Erich Schmidt Verlag, Berlin. 
Gardeła, Leszek

2013 'Warrior-women' in Viking Age Scandinavia? A preliminary archaeological study. Analecta Archaeological Gicaressoviensia 8: 273-341.

Green, Dennis

2002 Discussion. In The Scandinavians from the Vendel Period to the Tenth century: An Ethnographic Perspective, edited by Judith Jesch, p. 119. The Boydell Press, Woodbridge.

Green, Dennis

2009 Linguistic and Literary Traces of the Langobards. In The Langobards. Before the Frankish Conquest: An Ethnographic Perspective, edited by Giorgio Ausenda, Paolo Delogu and Chris Wickham, pp. 174-94. The Boydell Press, San Marino.

Grundtvig, Sven

1871 Om de Gotiske Folks Våbenéd. Det Kgl. Videnskabernes Selskab, København.

Grünzweig, Friedrich E

2009 Das Schwert bei den 'Germanen'. Kulturgeschichtliche Studien zu seinem 'Wesen'vom Altertum bis ins Hochmittelalter. Fassbaender, Wien.

Hedeager, Lotte

2011 Iron Age Myth and Materiality: An Archaeology of Scandinavia AD 400-1000. Routledge, Taylor and Francis Group, London.

Helmbrecht, Michaela

2019 The gold foil figures within the imagery of the Vendel Period and the continuation of their motifs into the Viking Age. In Gold foil figures in focus: A Scandinavian find group and related objects and images from ancient and medieval Europe, edited by Alexandra Pesch and Michaela Helmbrecht, pp. 131-50. Verlag Dr. Friedrich Pfeil, München.

Hertzberg, Ebbe

1874 Grundtrcekkene i den celdste norske proces. Aschehoug, Kristiania.

Heusler, Andreas

1911 Das Strafrecht der Isländersagas. Duuncker \& Humblot, Leipzig.

Hodne, Bjarne

1973 Personalhistoriske sagn: en studie i kildeverdi. Universitetsforlaget, Oslo.

Hofseth, Ellen Høigård

1982 Loven om våpenting sett $\mathrm{i}$ lys av arkeologisk materiale. In Universitetets Oldsaksamling Arbok 1980/81, edited by Egil Mikkelsen, pp. 103-18. Oldsaksamlingens tryknings og publikasjonsutvalg, Universitetets Oldsakssamling, Oslo.

Holmbäck, Åke and Elias Wessén (editors and translators)

1946 Svenska landskapslagar, tolkade och förklarade för nutidens svenskar. Femte serien. Äldre Västgötalagen, Yngre Västgötalagen, Smålandslagens kyrkobalk och Bjärköarätten. Gebers, Stockholm.

Holtsmark, Anne

1941 Kong Atles eder, Maal og Minne: 1-10.

Hreinsson, V (editor and translator)

1997 The Complete Sagas of Icelanders: Including 49 tales. 5 vol. Leifur Eiríksson Publishing, Reykjavík.

Hüpper-Dröge, Dagmar

1981 Schutz- und Agriffswaffen nach den Leges und verwandten Fränkischen Rechtsquellen. In Wörter und Sachen im Lichte der Bezichnungsforschung. Arbeiten zur Frühmittelalterforschung. Schriftenreihe des Instituts für Frühmittelalterforschung der Universität Münster, edited by Karl Hauck, pp. 107-27. Walter de Gruyter, Berlin.

Iversen, Tore

1977 Trelldommen: norsk slaveri i middelalderen. Historisk Institutt, Universitetet i Bergen, Bergen. 
Kienast, Walther

1984 Gefolgswesen und Patronicium im Spanischen Westgotenreich. Historische Zeitschrift 239: $23-75$.

Larrington, Carolyne (editor and translator)

1996 The Poetic Edda. Oxford University Press, Oxford.

Larson, Laurence $\mathrm{M}$ (editor and translator)

1935 The Earliest Norwegian Laws Being the Gulathing Law and the Frostathing Law. Columbia University Press, New York.

Miller, Geoffrey P

2005 The Legal Function of Ritual. Chicago-Kent Law Review 80 (3): 1181-239.

Moen, Marianne

2019 Challenging Gender: A reconsideration of Gender using the mortuary landscape. $\mathrm{PhD}$ thesis University of Oslo, Oslo.

Munch, P. A, R. Keyser, G. Storm and E. Hertzberg (editors)

1846-95 NgL: Norges gamle Love indtil 1387. 5 vol. Chr. Grøndahl, Christiania.

Mundal, Else

2012 The Relationship Between Heathens and Christians in Scandinavia in the Time Before Christianisation. In The Creation of Medieval Northern Europe. Christianisation, Social Transformations, and Historiography. Essays in Honour of Sverre Bagge, edited by Leidulf Melve and Sigbjørn Sønnesyn, pp. 70-89. Dreyer Forlag A/S, Oslo.

1994 The position of women in Old Norse society and the basis for their power. Nora 1: 3-11.

Neckel, Gustav and Hans Kuhn (editors)

1983 Edda: die Lieder des Codex Regius nebst verwandten Denkmälern. I. Text. 5. verbesserte Auflage. Carl Winter, Universitätsverlag, Heidelberg.

Oliver, Lisi

2011 The Body Legal in Barbarian Law. University of Toronto Press, Toronto.

Patera, Ioanna

2012 Ritual Practice and Material Support: Objects in Ritual Theories. CHS Research Bulletin 1 (1). [https://research-bulletin.chs.harvard.edu/2012/11/30/ritual-practice-and-material-supportobjects-in-ritual-theories/] last accessed 28.06.21.

Peters, Edward and William Dudley Foulke (editors and translators)

2003 History of the Lombards. Paul the Deacon. University of Pennsylvania Press, Philadelphia.

Rappaport, Roy A

1999 Ritual and Religion in the Making of Humanity. Cambridge University Press, Cambridge

Reuter, Timothy (translator)

1992 The Annals of Fulda. Manchester University Press, Manchester.

Riisøy, Anne Irene

2020 Volundr: a Gateway into the Legal World of the Vikings. In Narrating Law and Laws of Narration in Medieval Scandinavia, Ergänzungsbände zum Reallexikon der Germanischen Altertumskunde 117, edited by Roland Scheel, pp. 255-74. De Gruyter, Berlin.

2016 a Performing Oaths in Eddic Poetry: Viking Age Fact or Medieval Fiction? Journal of the North Atlantic 8: 141-56.

2016 b Eddic Poetry: A Gateway to Late Iron Age Ladies of Law. Journal of the North Atlantic 8: $157-71$.

Rives, J. B (editor and translator)

2002 Tacitus, Germania. Clarendon Press, Oxford.

Robberstad, Knut (editor and translator)

1969 Gulatingslovi. Det Norske Samlaget, Oslo.

Røsstad, Rune

1997 A tveim tungum: om stil og stilvariasjon i norrønt lovmål. Noregs forskingsråd, Oslo. 
Sanmark, Alexandra

2014 Women at the Thing. In Kvinner $i$ Vikingtid, edited by Nancy Coleman and Nanna Løkka, pp. 89-106. Scandinavian Academic Press, Oslo.

Schjødt, Jens Peter

2012 Reflections on Aims and Methods in the Study of Old Norse Religion. In More than Mythology. Narratives, Ritual Practices and Regional Distribution in Pre-Christian Scandinavian Religions, edited by Catharina Raudvere and Jens Peter Schjødt, pp. 263-87. Nordic Academic Press, Lund.

Schjødt, Jens Peter

2008 Initiation Between Two Worlds: Structure and Symbolism in Pre-Christian Scandinavia Religion. The University Press of Southern Denmark, Odense.

Scholz, Bernhard Walter and Barbara Rogers (editor and translator)

1970 Carolingian Chronicles: Royal Frankish Annals and Nithard's Histories. The University of Michigan Press, Ann Arbor.

Sherbowitz-Wetzor Olgerd P and Samuel Hazzard Cross (editors and translators)

1953 The Russian Primary Chronicle: Laurentian text. Mediaeval Academy of America, Cambridge, Mass.

Sigurðardóttir, Aldís, Alex Speed Kjeldsen, Bent Chr. Jacobsen, Christopher Sanders, Ellert Pór

Jóhannsson, Eva Rode, Helle Degnbol, James E. Knirk, Johnny Lindholm, Maria Arvidsson, Simonetta

Battista, Tarrin Wills, Porbjörg Helgadóttir (editors)

Sverðtakari, Dictionary of Old Norse Prose [https://onp.ku.dk/onp/onp.php?o77643], last accessed 24.05.2021.

Siðr, Dictionary of Old Norse Prose [https://onp.ku.dk/onp/onp.php?o68268], last accessed 24.05.2021

Skre, Dagfinn

2017 Monetary Practices in Early Medieval Western Scandinavia $\left(5^{\text {th }}-10^{\text {th }}\right.$ Centuries AD). Medieval Archaeology 61: 277-99.

Solberg, Bergljot

1985 Social Status in the Merovingian and Viking Periods in Norway from Archaeological and Historical Sources. Norwegian Archaeologica Review 18 (1-2): 61-76.

Steenstrup, Johannes

1878 Normannerne, vol. II, Vikingetogene mod vest i det 9 de aarhundrede. I. Cohens bogtrykkeri, Kjøbenhavn.

Stein-Wilkeshuis, Martina

2002 Scandinavians Swearing Oaths in Tenth-Century Russia: Pagans and Christians. Journal of Medieval History 28: 155-68.

Sørensen, Meulengracht Preben

1983 The Unmanly Man: Concepts Of Sexual Defamation In Early Northern Society. Odense University Press, Odense.

Sävborg, Daniel

2004 Om eddadikternas ursprung och ålder: gamla och nya tankar. Arkiv för nordisk filologi 119: 55-104.

Tamm, Ditlev

2018 The Liber legis Scaniae. The Latin Text with Introductions, Translation and Commentaries. Routledge, London and New York.

Thorvaldsen, Bernt Øyvind

2010 The Poetic Curse and Its Relatives. In Along the Oral-Written Continuum: Types of Texts, Relations and their Implications, edited by Slavica Rankovic, Leidulf Melve and Else Mundal, pp. 253-67. Brepols, Turnhout. 
Thorvaldsen, Bernt Øyvind

2016 The Dating of Eddic poetry. In A Handbook to Eddic Poetry. Myths and Legends of Early Scandinavia, edited by Carolyne Larrington, Judy Quinn, and Brittany Schorn, pp. 72-91. Cambridge University Press, Cambridge.

porgeirsson, Haukur

2016 The dating of Eddic poetry: Evidence from alliteration. In Approaches to Nordic and Germanic Poetry, edited by K. Árnason, pp. 257-78. University of Iceland Press, Reykjavik.

Tschan, Francis J, and Timothy Reuter (translators)

2002 History of the Archbishops of Hamburg-Bremen/Adam of Bremen. Columbia University Press, New York.

Vedeler, Marianne

2018 The Charismatic Power of Objects. In Charismatic Objects. From Roman Times to the Middle Ages, edited by Marianne Vedeler, Ingunn Marit Røstad, Siv Kristoffersen and Ann Zanette Tsigaridas Glørstad, pp. 9-29. Cappelen Damm Akademisk, Oslo.

Wormald, C. Patrick

2003 'Leges Barbarorum': Law and Ethnicity in the Post-Roman West. In Regna and Gentes: The Relationship between Late Antique and Early Medieval Peoples and Kingdoms in the Transformation of the Roman World, edited by Hans-Werner Goetz, Jörg Jarnut and Walter Pohl, pp. 21-53. Brill, Leiden.

Øyrehagen Sunde, Jørn

2007 De skal vera samde menn - Ei vitskapleg fundering og spekulasjon over den eldste norske prosessen. In Eftersyn och eftertanke: festskrift till Göran Inger. De Lege - Juridiska Fakulteten i Uppsala Årsbok 2007, edited by Petter Asp, pp. 305-22. Iustus förlag, Uppsala. 

